\title{
Numerical investigation of hydrogen consumption in Proton Exchange Membrane Fuel Cell by using computational fluid dynamics (CFD) simulation
}

\author{
Yassine Amadane 1,*, Hamid Mounir ${ }^{1}$, Abdellatif El Marjani ${ }^{1}$, Ettouhami Mohamed Karim ${ }^{2}$ and \\ Asifa Awan ${ }^{3}$ \\ ${ }^{1}$ Research Team EMISys, Research Center Engineering 3S, School Mohammadia of Engineers, Mohamed V \\ University of Rabat, Morocco \\ ${ }^{2}$ Centre de Recherche en Sciences et Technologies de l'Ingénieur et la Santé, ENSET, Mohamed V University \\ of Rabat, Morocco \\ ${ }^{3}$ Institute of Chemical Engineering, University of the Punjab, Lahore, Pakistan
}

\begin{abstract}
Proton exchange membrane fuel cell (PEMFC) is the most important system that converts chemical energy into electricity by using hydrogen oxidation and oxygen reduction reactions. With this approach, a 3-D (CFD) thermo-fluid model was studied using a commercial code ANSYS fluent for investigating the performance of the PEMFC system. The developed model can evaluate the distribution of gas species like the mass fraction of hydrogen, as well as the distribution of water in PEMFC. The results are used to investigate the influence of temperature and cell voltage on the consumption of hydrogen from inlet $\mathrm{z}=0 \mathrm{~mm}$ to outlet $\mathrm{z}=50 \mathrm{~mm}$. The obtained polarization curve I-V is compared with the literature findings. The analysis shows a good agreement between our findings and the experimental results. The CFD simulation shows that the cell voltage affects considerably the hydrogen consumption; at $333 \mathrm{~K}$, it can be seen that the hydrogen mass fraction decreases from $80 \%$ to $67 \%$ at $0.7 \mathrm{~V}$ and $80 \%$ to $73 \%$ at $0.9 \mathrm{~V}$. By comparing the hydrogen mass fractions; at a low cell voltage the hydrogen mass fraction dropped by only $7 \%$, while at a high cell voltage the hydrogen mass fraction dropped by about $13 \%$ from the inlet to outlet. Consequently; our analyses show high consumption of hydrogen at low cell voltages.
\end{abstract}

Keywords: PEMFC; consumption; hydrogen; CFD; ANSYS.

\section{Introduction}

Proton exchange membrane fuel cells or (PEMFCs) have had a major revolution regarding research aimed at their theoretical understanding and modelling ${ }^{1}$. Proton exchange membrane (PEM) fuel cells are the current focus of research for fuel cell vehicle applications. PEM fuel cells are thus likely to play a key part in green energy economies based essentially on energy efficiency and renewable energy ${ }^{2}$. Elseways, the architecture of PEM fuel cells is a quite complex (due to lots of input parameters need to be considered when developing PEM fuel cell designs) multi-physics task that is greatly facilitated by a computer simulation modelling incorporating all the necessary theoretical equations. The main advantages of PEMFC when compared to a solid oxide fuel cell (SOFC) and Direct methanol fuel cell (DMFC) is that they have high efficiency and they are also able to operate in low temperatures around $80{ }^{\circ} \mathrm{C}^{3}$. The use of fuel *Corresponding author: Yassine Amadane Email address : yassineamadane@research.emi.ac.ma DOI: http://dx.doi.org/10.13171/mjc7618121415ya cells for automotive applications needs hydrogen technologies ${ }^{4}$. Hydrogen produced from renewable energy sources such as solar and wind energy, stored as a compressed gas, liquid or in the solid state, and then used in fuel cells to produce electricity, offers an attractive, sustainable energy option for transport and stationary applications ${ }^{5}$. Recently, many researchers have been investigated and developed a thermo-fluid model of a proton exchange membrane fuel cell with a straight flow channel. Many papers have been studied the single-channel design of PEMFC to analyze the distribution of gas species $\left(\mathrm{H}_{2}\right.$ and $\mathrm{O}_{2}$ ) and especially the hydrogen consumption along the anode channel. A three-dimensional model to study the influence of different parameters on (PEM) fuel cell performance (geometry, materials) is simulated and presented by Sadiq Al-Baghdadi and Shahad Al-Janabi ${ }^{6}$. Lin et al ${ }^{7}$. showed the dependence between the mass fraction of oxygen and the overpotential.

Received September 25, 2018

Accepted November 3, 2018

Published December 14, 2018 
Tolj et al. ${ }^{8}$ studied the PEMFC performance for non-uniform temperature, the single cell was divided into five equal parts, and the experimental results have shown significant improvement when compared to the isothermal case. Hinatsu et al. ${ }^{9}$ have proposed a model for membrane water by changing the temperature from $25^{\circ}$ to $130^{\circ}$. Ozden et al. ${ }^{10}$ proposed a three-dimensional computational fluid dynamics model from Tolj et al. ${ }^{8}$. In the study of Hashemi et al. ${ }^{11}$ a comprehensive non-isothermal model has been established to investigate the performance of PEMFC with straight and serpentine flow fields. The model considers the major electrochemical phenomena, oxygen and hydrogen mass fractions distribution. In Mahayri's paper ${ }^{12}$ a transient multiphase in a dead end anode model is investigated for modelling and simulation. In $\mathrm{H}$. Kazemi Esfeh et al.'s paper ${ }^{13}$ a CFD model of a serpentine PEMFC was carried out.
The use of the ANSYS module to simulate our PEMFC with a single flow channel is presented. The main objective of this study is to understand the consumption of hydrogen of a PEMFC with a single flow channel. The ANSYS model has been created to analyze the mass fraction of hydrogen and water. The consumption of hydrogen along the anode channel was discussed. Our model is also used to investigate the impact of changing the voltage on the hydrogen consumption and water dynamics.

A fuel cell is a system that uses hydrogen and oxygen to produce electricity by an electrochemical reaction, as shown in (Fig.1). There are different types of fuel cells, such as Alkaline Fuel Cell (AFC), Solid Oxide Fuel Cell(SOFC), Proton Exchange Membrane Fuel Cell (PEMFC), Molten Carbonate Fuel Cell (MCFC) etc. The classification these types based on the type of electrolyte ${ }^{1}$. In this paper, we will focus our study on the proton exchange membrane fuel cell.

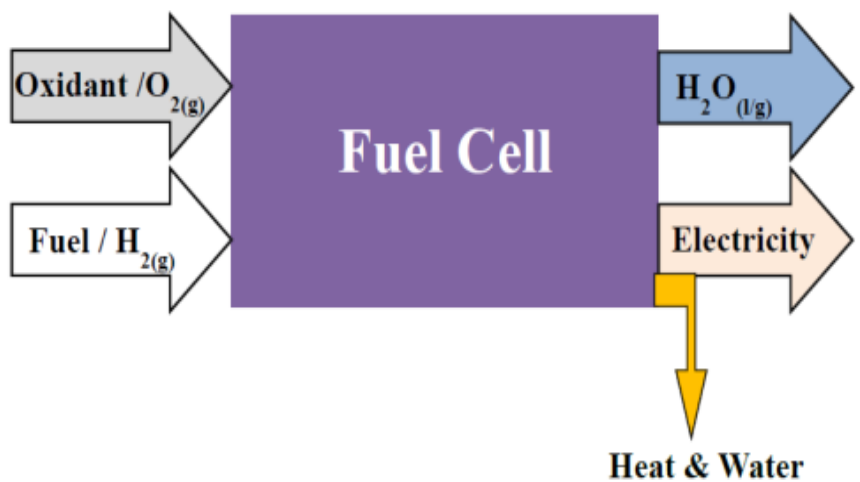

Figure 1. Schematic of the fuel cell system.

\section{Mathematical model}

A 3-D finite element model was created using ANSYS code and taking into account phenomena involving transport in the membrane, GDL, catalyst layer. The description of PEMFC is presented in (Fig. 2) ${ }^{14}$.

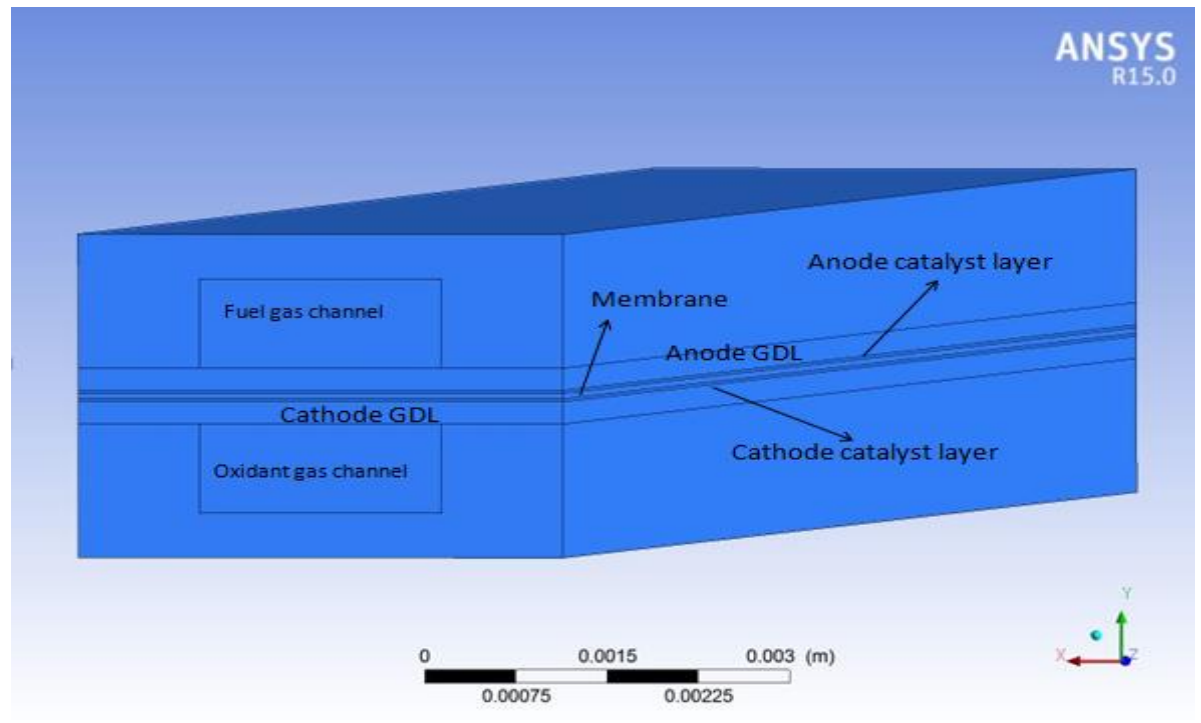

Figure 2. Description of PEM fuel cell 
Hydrogen gas passes into the anode side. It diffuses through the (GDL) and reaches the catalyst layer (CL), where it forms ions and electrons. The hydrogen ions diffuse through the membrane, and electrons flow through the anode (GDL) to the current collectors (CC). The electrons enter the cathode side through the current collectors and the gas diffusion layer. Upon reaching the cathode catalyst layer, the electrons, hydrogen ions and oxygen combine to form water and release heat ${ }^{15}$.

The elementary PEM fuel cell consists of two catalyst layers, two gas diffusion layers, current collectors and membrane ${ }^{16}$. The PEM fuel cell components are summarized in (Table. 1).

Table 1. (PEMFC) components and materials.

\begin{tabular}{|c|c|c|}
\hline PEMFC parts & Materials & Properties \\
\hline Current collectors & Gold plating & High electrical and thermal conductivities. \\
\hline Catalyst Layers & Platinum & Performs electrochemical reaction \\
\hline Gas diffusion layers & Carbon fiber & $\begin{array}{l}\text { Conduct electrons between the bipolar } \\
\text { plate and electrode }\end{array}$ \\
\hline Membrane & Nafion & Transfer protons \\
\hline
\end{tabular}

The governing equations are formulated under the following assumptions ${ }^{11}$ :

\section{Assumptions:}

Steady-state system

Isothermal condition (temperature constant)

The flow is laminar

GDL: Isotropic and homogeneous

Activation over potentials: Constant within anode and cathode

Incompressible fluids

Bulter-Volmer equations for electrochemical reaction

All simulations presented in this work are performed by using ANSYS-Fluent software 15.0.
The four basic steps of our simulation study are presented in Fig.3:

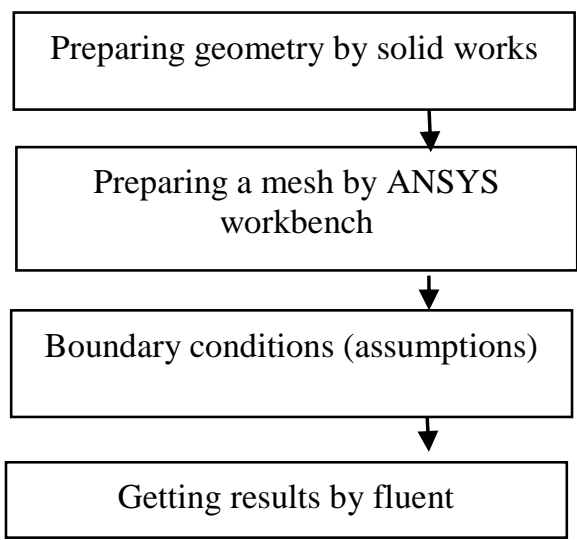

Figure 3. Steps of modelling 
Thermo fluid model

Thermo-fluid model - Governing equations

This section described the governing transport equations used for this research work. These governing equations were selected by the literature review of the work done by a different researcher. The fluid and temperature fields in the whole domain are obtained by solving the steady-state NavierStokes equations, consisting of the continuity equation, the momentum equations and the mass conservation equation for each species, and the energy conservation equation:

- Continuity equation:

This equation represents the mass conservation for all transport phenomena that take place in the fuel cell, and it is described as:

$\nabla(\rho \vec{u})=\mathrm{S}_{m}$

Where $\rho$ is the density.

- Momentum conservation:

The momentum transport equation in a steady-state is written as:

$$
\nabla(\rho \vec{u} \vec{u})=-\nabla p+\nabla(\mu \nabla \vec{u})+\mathrm{S}_{u}
$$

Where $\mathrm{p}$ is the pressure

- Species conservation:

The species transport equation represents the mass conservation for all gas species, and it is defined as:

$\nabla\left(\vec{u} C_{i}\right)=\nabla\left(\mathrm{D}_{i}^{e f f} \nabla C_{i}\right)+\mathrm{S}_{i}$

Where $\mathrm{D}_{i}^{\text {eff }}$ is the effective diffusivity

- Energy conservation:

The energy equation is written as:

$\nabla\left(\rho C_{p} \vec{u} T\right)=\nabla\left(k^{e f f} \nabla T\right)+\mathrm{S}_{T}$

Where $k^{\text {eff }}$ is the effective thermal conductivity

\section{Source terms}

Table 2. Boundary conditions.

Table 2. Boundary conditions.
All the source terms appearing in the governing equations are:

$S_{m}$ : Source term for continuity equation.

$S_{u}$ : Source term for momentum equation.

$S_{i}$ : Source term for the species inside catalyst layers.

$S_{T}$ : Source term for the energy equation.

\section{Electrochemical model}

The fluid dynamics equations are coupled at the electrochemical model implemented in ANSYSFluent.

$\nabla\left(\sigma_{m}{ }^{e f f} \nabla \Phi_{m}\right)+\mathrm{R}_{m}=0$

Equation (5) associated with the protons transport the membrane and catalyst layers

$\nabla\left(\sigma_{S}^{e f f} \nabla \Phi_{S}\right)+\mathrm{R}_{S}=0$

Equation (6) associated with the electrons transport in catalyst layers and gas diffusion layers. Where $\sigma$ is the electric or ionic conductivity, $\Phi$ is the cell potential and $\mathrm{R}$ is the transfer current. The transfer current and source terms are determined from the general Butler-Volmer formulation.

The membrane is simulated as a porous zone, and its properties as ionic conductivity $\sigma_{m}$ and the electroosmotic drag coefficient are expressed as a function of the water content $\lambda^{18}$.

$\sigma_{m}=(0.00514 \lambda-0.00326) \exp (1268(1 / 300-1 / T))$

$\lambda=0.043+17.81 a-39.84 a^{2}+36 a^{3}(\mathrm{a}<1)$

$\lambda=14+1.4(\mathrm{a}-1)(\mathrm{a}>1)$

Where a is the water activity. This model is used to simulate the formation and transport of water in the fuel cell.

\section{Boundary conditions}

In the current study, there are two types of external boundary conditions. We used the following equations to illustrate the boundary conditions as shown in (Table. 2) ${ }^{17}$.

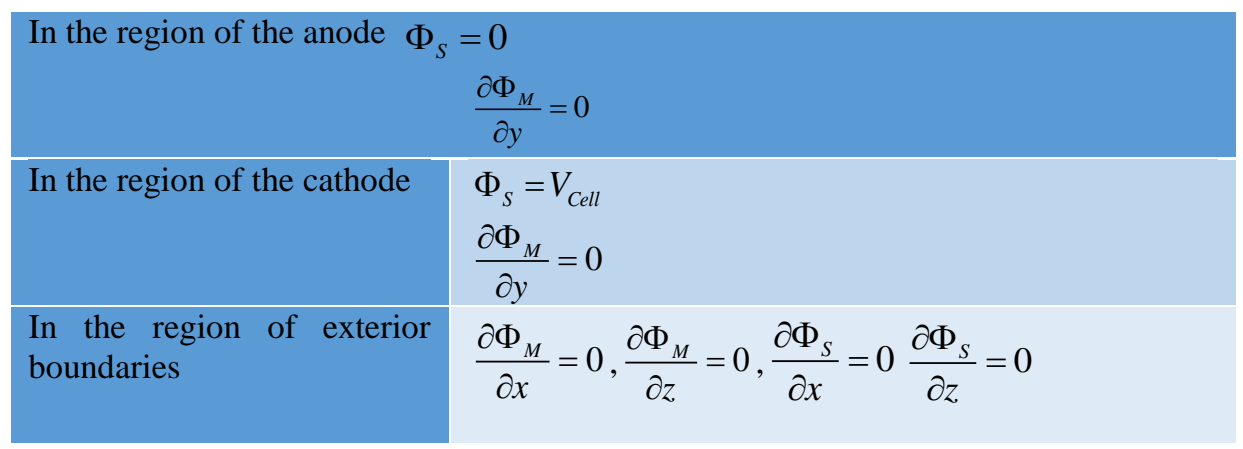


Details of calculations

\section{Geometrical modelling}

The design of our system in ANSYS is presented in (Fig.4). The geometry modelled is a $2.9 \mathrm{~mm} * 4 \mathrm{~mm} * 50 \mathrm{~mm}$. The anode side is for hydrogen, and the cathode side is for oxygen or air. The gas channel is $4 \mathrm{~mm}$ wide and $2 \mathrm{~mm}$ high. The thicknesses of the membrane, gas diffusion layer, catalyst layer are $0.15 \mathrm{~mm}, 0.3$ and $0.02 \mathrm{~mm}$ respectively as shown in (Table. 3).

Table 3. (PEM) fuel cell dimensions.

\begin{tabular}{|l|c|c|c|c|}
\hline Part & Length & Width & Height & Unit \\
\hline Gas channels & 50 & 2 & 1 & $\mathrm{~mm}$ \\
\hline Gas diffusion layer & 50 & 4 & 0.3 & $\mathrm{~mm}$ \\
\hline Catalyst layer & 50 & 4 & 0.02 & $\mathrm{~mm}$ \\
\hline Membrane & 50 & 4 & 0.15 & $\mathrm{~mm}$ \\
\hline Current collector & 50 & 4 & 1.5 & $\mathrm{~mm}$ \\
\hline
\end{tabular}

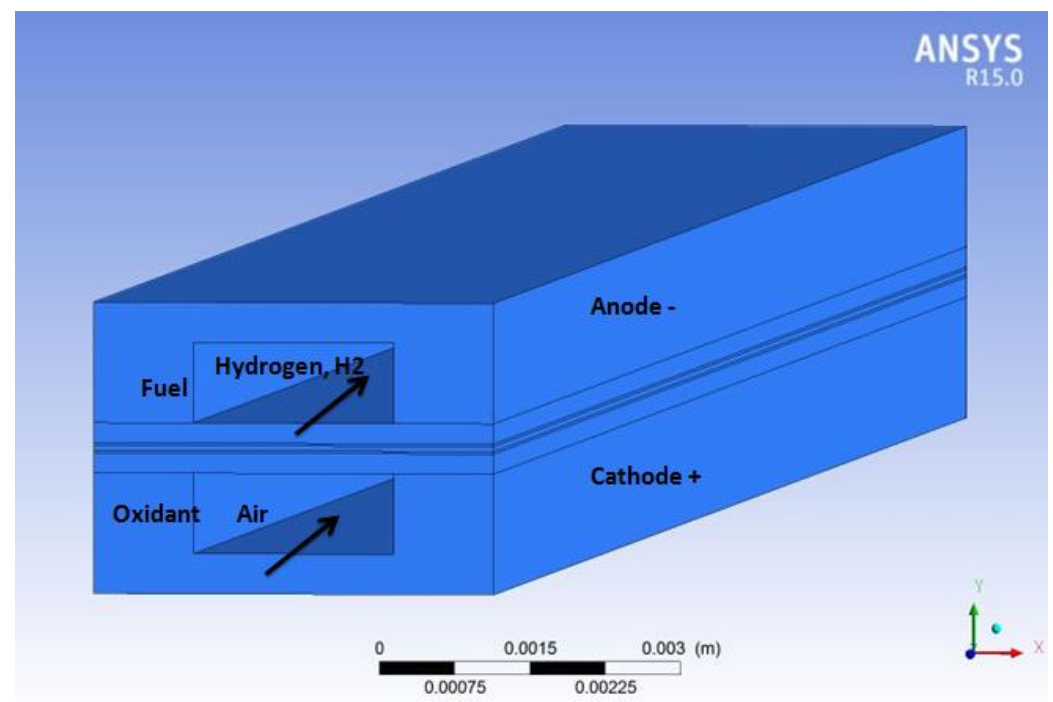

Figure 4. Schematic of PEMFC geometry
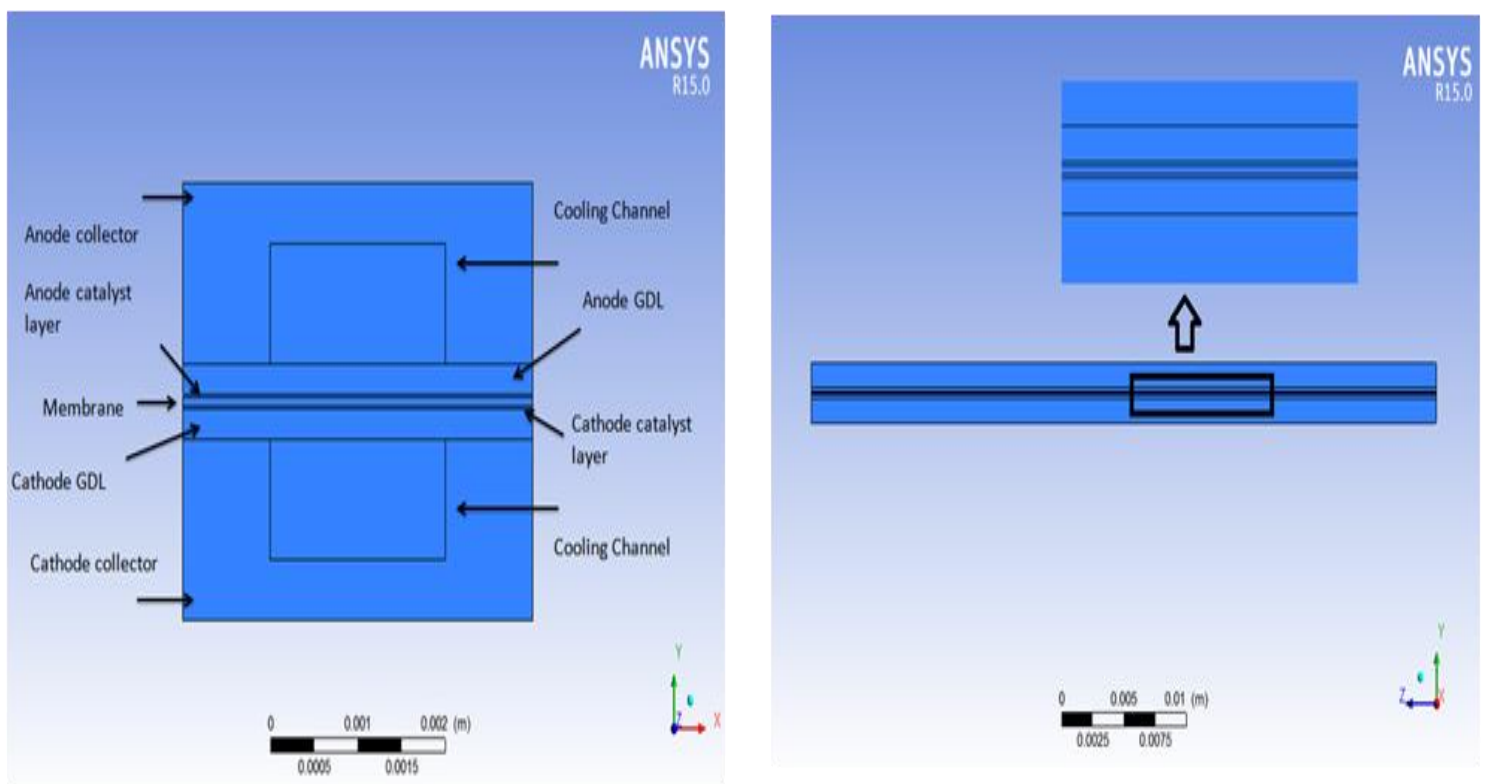

Figure 5. Schematic of a PEMFC: (a) XY plane, (b) YZ plane 
The basic case of a PEM fuel cell with a single straight gas flow channel on each side of the (MEA), the upper plate for hydrogen and the lower plate for air or oxygen, is presented in (Fig. 4) and (Fig. 5).

\section{Algorithm resolution}

The thermo-fluid model was studied using the ANSYS 15.0 code. This numerical code has an add- on module for fuel cells. A simple algorithm is used for solving equations (the mass, momentum and energy).

The number of iterations was determined as 1800. TOSHIBA-PC-Intel® Core (TM) i3-310M CPU@2.4 GHz, $2.4 \mathrm{GHz}$ was used to solve the problem.

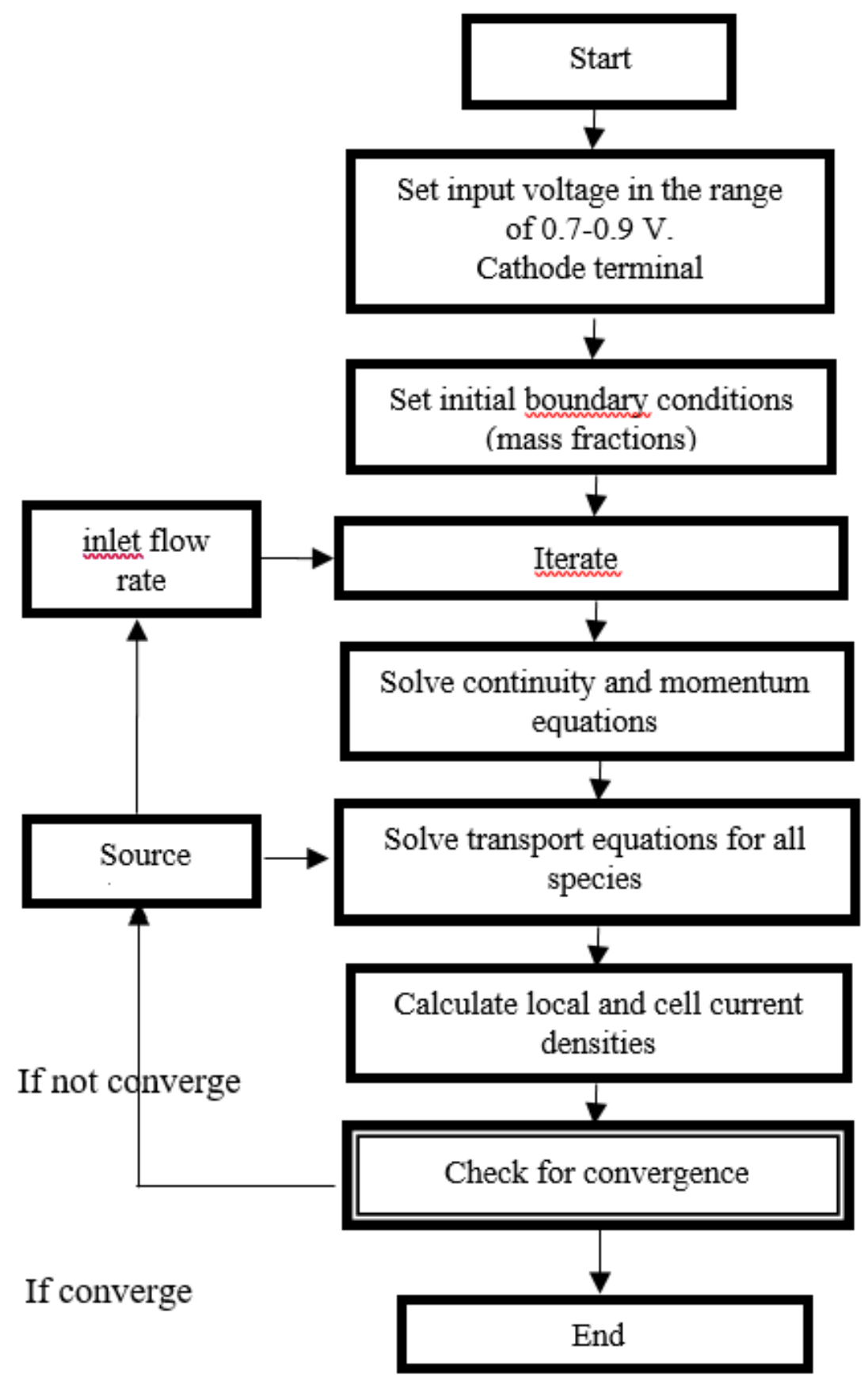

Figure 6. Solution algorithm used in Fluent

Parameters values

The numerical calculations are performed to evaluate the temperature and voltage influences on the hydrogen consumption in (PEMFC). The simulation takes about one hour for completing
1200 iterations. The boundary conditions of our iso-thermal model and the physical parameters are presented in the (Table. 4) and (Table. 5) respectively 
Table 4. Boundary conditions of our model.

\begin{tabular}{|c|c|c|c|c|}
\hline $\begin{array}{l}\text { Boundary } \\
\text { Conditions }\end{array}$ & Location & & Values & Units \\
\hline \multirow{6}{*}{$\begin{array}{l}\text { Velocity } \\
\text { inlet }\end{array}$} & \multirow[t]{3}{*}{ Inlet Anode } & Inlet gas velocity & 0.3 & $\mathrm{~m} / \mathrm{s}$ \\
\hline & & $\begin{array}{l}\text { Inlet hydrogen mass } \\
\text { fraction }\end{array}$ & 0.8 & - \\
\hline & & $\begin{array}{l}\text { Inlet water mass } \\
\text { fraction }\end{array}$ & 0.2 & - \\
\hline & \multirow[t]{3}{*}{ Inlet Cathode } & Inlet gas velocity & 0.5 & $\mathrm{~m} / \mathrm{s}$ \\
\hline & & $\begin{array}{l}\text { Inlet oxygen mass } \\
\text { fraction }\end{array}$ & 0.9 & - \\
\hline & & $\begin{array}{l}\text { Inlet water mass } \\
\text { fraction }\end{array}$ & 0.1 & - \\
\hline \multirow{2}{*}{$\begin{array}{l}\text { Pressure } \\
\text { Outlet }\end{array}$} & Outlet Anode & Outlet gas pressure & 0 & $\mathrm{~Pa}$ \\
\hline & Outlet Cathode & Outlet gas pressure & 0 & $\mathrm{~Pa}$ \\
\hline \multirow[t]{3}{*}{ Wall } & Terminal Anode & $\begin{array}{l}\text { Specified electric } \\
\text { potential }\end{array}$ & 0 & $\mathrm{~V}$ \\
\hline & Terminal Cathode & $\begin{array}{l}\text { Specified electric } \\
\text { potential }\end{array}$ & $0.7-0.9$ & V \\
\hline & All faces & Constant temperature & 343 & $\mathrm{~K}$ \\
\hline
\end{tabular}

Table 5. parameters values.

\begin{tabular}{|c|c|c|}
\hline Description & Value & Dimension \\
\hline Channel length & 50 & $\mathrm{~mm}$ \\
\hline Cell width & 2.9 & $\mathrm{~mm}$ \\
\hline Cell height & 4 & $\mathrm{~mm}$ \\
\hline Cell temperature & $333 / 343 / 353$ & $\mathrm{~K}$ \\
\hline Anode pressure & 2 & $\mathrm{~Pa}$ \\
\hline Cathode pressure & 2 & $\mathrm{~Pa}$ \\
\hline Concentration exponent & 0.5 & - \\
\hline Open circuit voltage & 0.95 & volts \\
\hline Exchange coefficient & 2 & - \\
\hline Mass flow rate (Anode) & $10^{-6}$ & $\mathrm{~kg} / \mathrm{s}$ \\
\hline Mass Flow rate (Cathode) & $10^{-5}$ & $\mathrm{~kg} / \mathrm{s}$ \\
\hline Equivalent weight (membrane) & 1100 & $\mathrm{~kg} / \mathrm{kmol}$ \\
\hline $\begin{array}{l}\text { Protonic conduction (coefficient and } \\
\text { exponent) }\end{array}$ & 1 & - \\
\hline
\end{tabular}


The operating pressure of the $\mathrm{H}_{2}$ inlet is 1 bar gauge, with a 0.8 mass fraction for $\mathrm{H}_{2}$, and 0.2 for water. The operating pressure of the $\mathrm{O}_{2}$ inlet is 1 bar gauge, with a mass fraction of 0.9 for $\mathrm{O}_{2}$, and 0.1 for water.
In the next section, we will present a simulation of a single PEMFC by using ANSYS Fuel Cell Module.

\section{Results and Discussion \\ Thermo-fluid model validation}

Table 6. Comparison of the current density of experiment and simulation

\begin{tabular}{|c|c|c|c|c|c|}
\multicolumn{2}{|c|}{ Our model } & \multicolumn{2}{c|}{ Experimental data } & \\
\hline $\begin{array}{l}\text { Current } \\
\left.\text { density(A/cm }{ }^{2}\right)\end{array}$ & Voltage(V) & $\begin{array}{l}\text { Current } \\
\text { density }\left(\mathrm{A} / \mathrm{cm}^{2}\right)\end{array}$ & Voltage(V) & $\begin{array}{l}\text { Difference of } \\
\text { current densities }\end{array}$ & Percentage \\
\hline 0.884657 & 0.7 & 0.78 & 0.7 & 0.104657 & $13.41 \%$ \\
\hline 0.372922 & 0.8 & 0.33 & 0.8 & 0.043922 & $13.30 \%$ \\
\hline 0.143458 & 0.85 & 0.12 & 0.85 & 0.023458 & $19.54 \%$ \\
\hline 0.027492 & 0.9 & 0.022 & 0.9 & 0.005492 & $24.96 \%$ \\
\hline
\end{tabular}

By comparing the difference of current densities as shown in (Table. 6), at $0.9 \mathrm{~V}$ the current density of our model was higher than the experiment by $24.96 \%$.

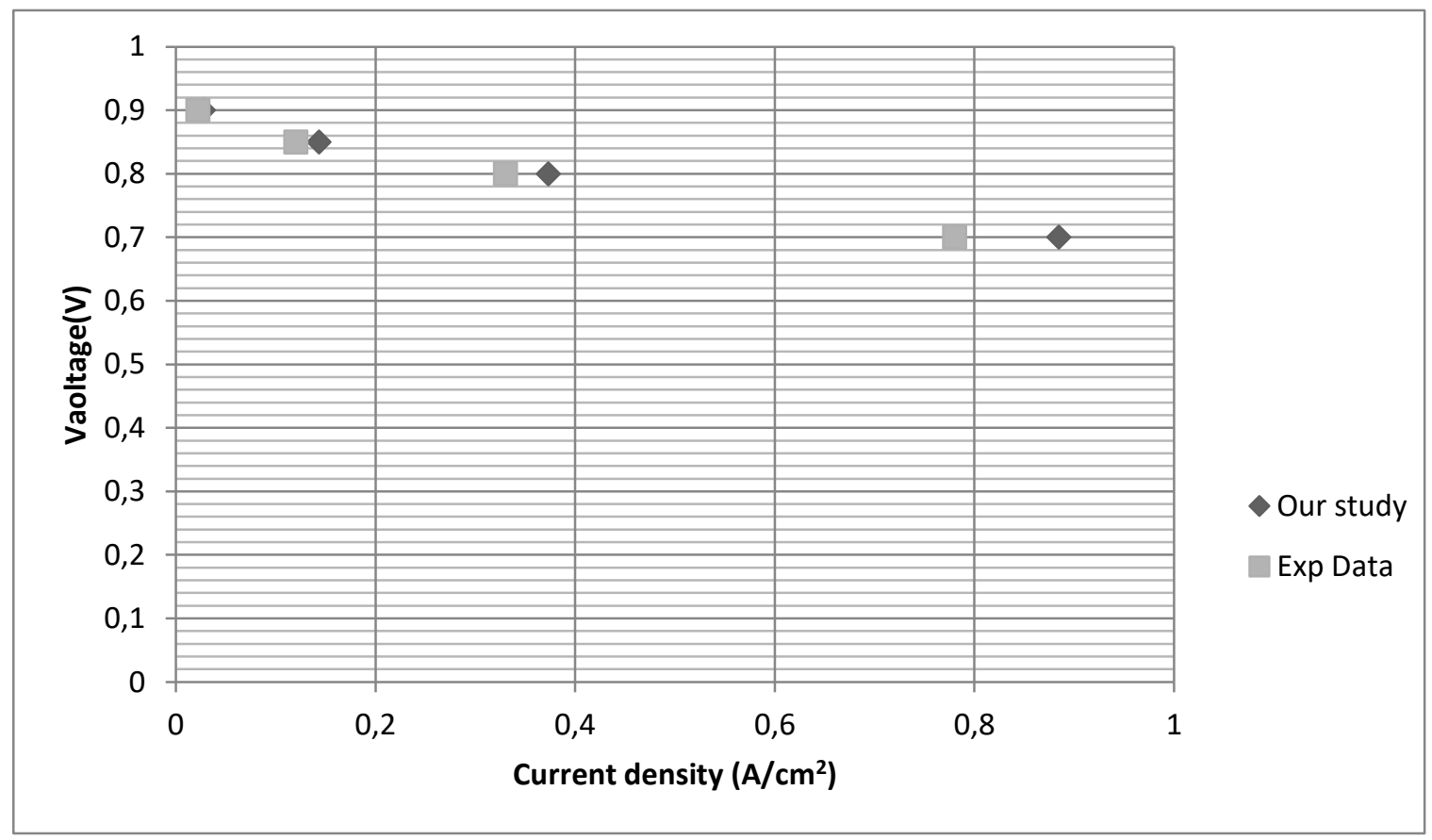

Figure 7. Validation of thermo-fluid model ${ }^{19}$

Fig.7 represents the comparison between our numerical findings and experimental results ${ }^{19}$. The maximum current densities: $0.884657 \mathrm{~A} / \mathrm{cm}^{2}$ at $0.7 \mathrm{~V}$ for the present model, $0.78 \mathrm{~A} / \mathrm{cm}^{2}$ at $0.7 \mathrm{~V}$ for experiment. In the middle range of voltage, the current densities of the present work were similar than the experiment. Our study presented the result in a reasonable range of the real PEM fuel cell.

In the following subsection, the hydrogen mass fraction distribution will be discussed. The temperature and voltage were varied $333 \mathrm{~K}, 343 \mathrm{~K}$ and $353 \mathrm{~K}$ at $0.7 \mathrm{~V}$ and $0.9 \mathrm{~V}$ respectively. 
Distribution of hydrogen's mass fraction in PEMFC

For $333 \mathbf{K}$

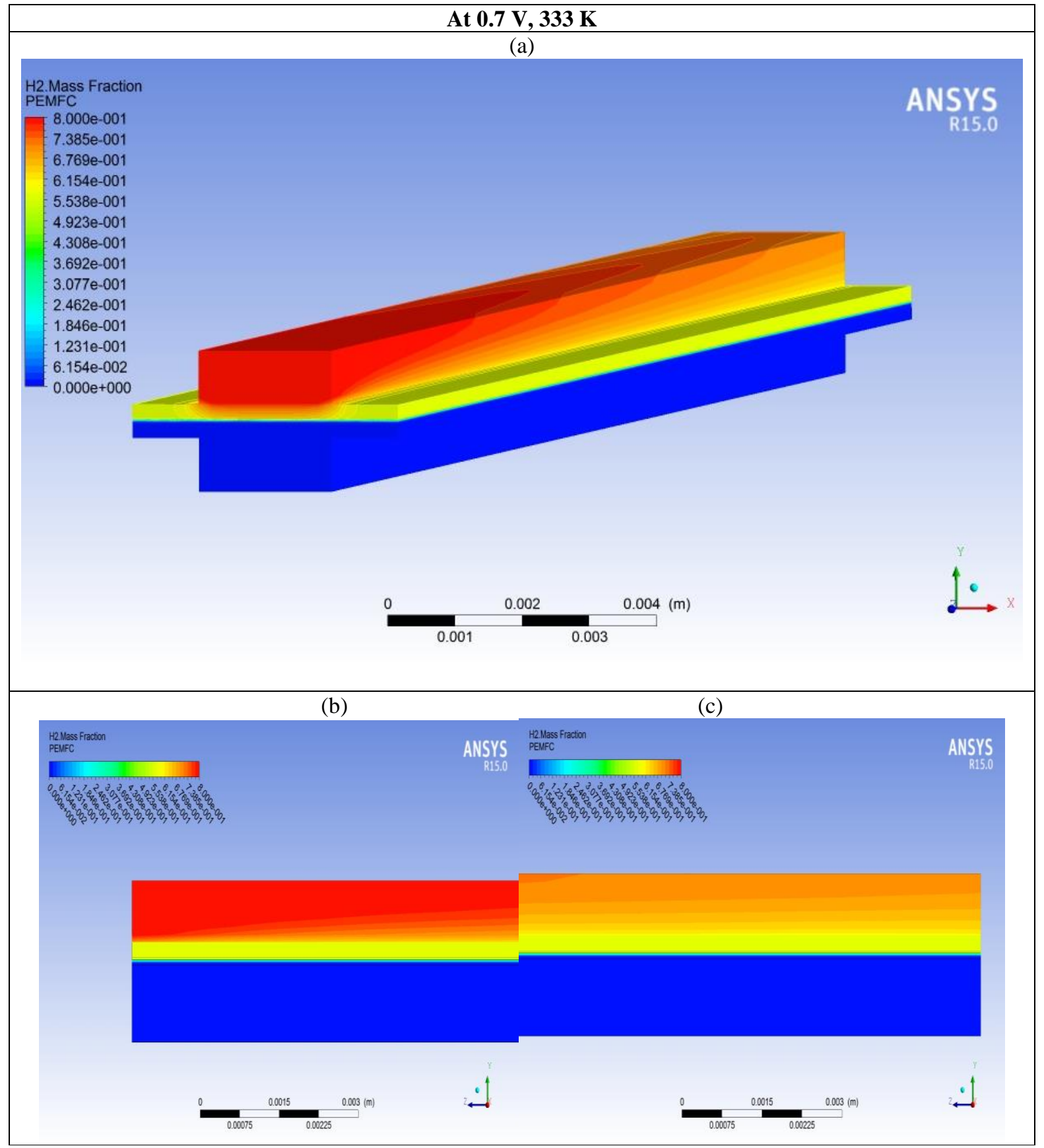

Figure 8. Three-dimensional distribution of hydrogen mass fraction at anode side: (a) Three-dimensional model, (b) The beginning of the anode channel, (c) the end of the anode channel, 333K. 


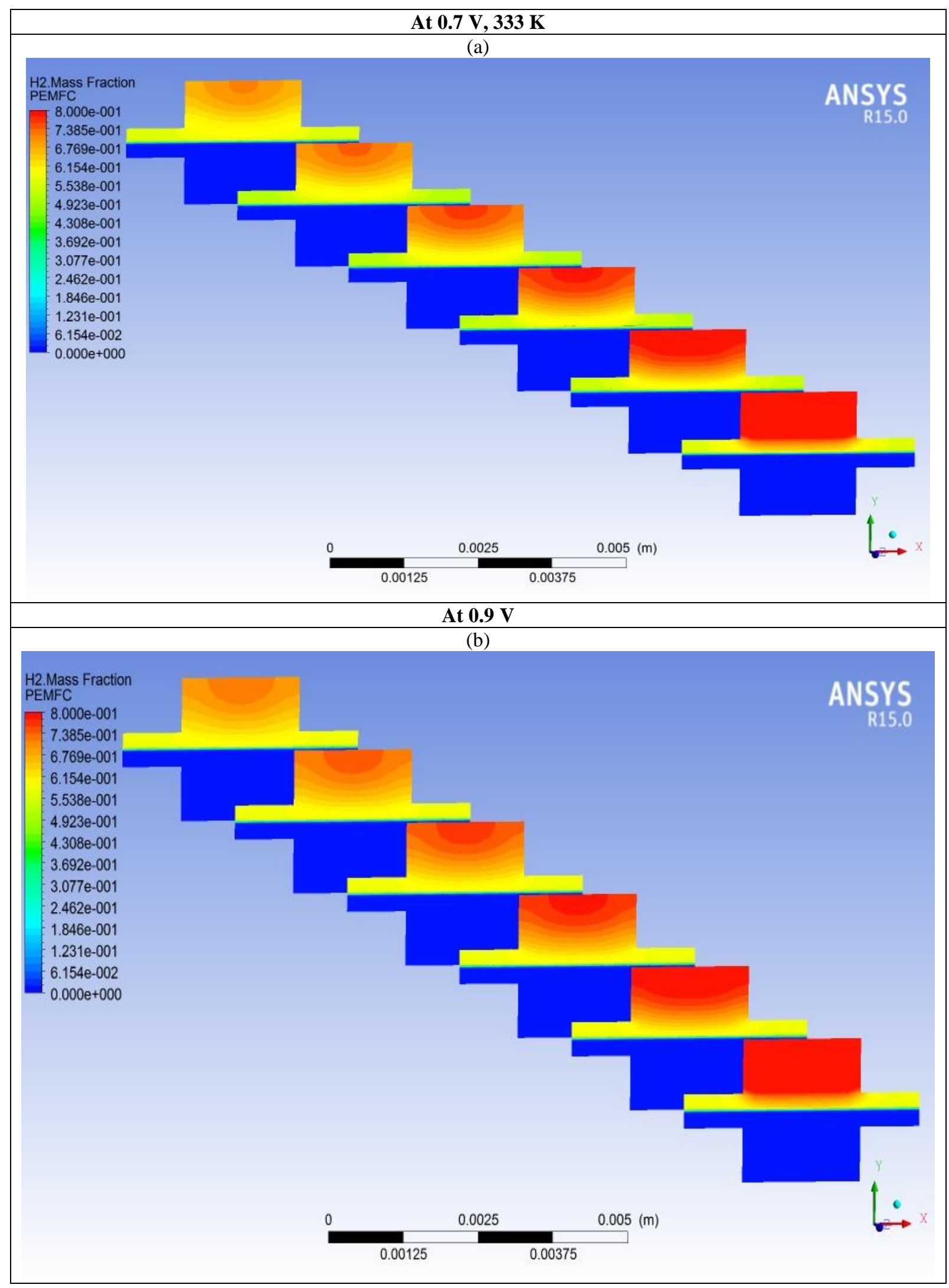

Figure 9. Hydrogen mass fraction distribution in PEMFC, (a) $0.7 \mathrm{~V}$ and (b) $0.9 \mathrm{~V}$ at $\mathrm{T}=333 \mathrm{~K}$. For six planes $\mathrm{z}=0.0 \mathrm{~mm}, \mathrm{z}=10 \mathrm{~mm}, \mathrm{z}=20 \mathrm{~mm}, \mathrm{z}=30 \mathrm{~mm}, \mathrm{z}=40 \mathrm{~mm}$ and $\mathrm{z}=50 \mathrm{~mm}$.

It is very important to know the hydrogen transport along the anode side in order to improve the performance of (PEM) fuel cell. Fig. 8 shows the three-dimensional contour of the mass fraction of hydrogen at the anode channel. 
In (Fig. 9(b)) showing the hydrogen distribution in the $\mathrm{y}$-z plane at $333 \mathrm{~K}$, the hydrogen mass fraction decreased along the flow channel. This decrease of hydrogen mass fraction along the anode channel was caused by the hydrogen consumption at $\mathrm{V}=0.7 \mathrm{~V}^{20,21,22}$.

Our simulation results are generated with two cell voltages of $0.7 \mathrm{~V}$ and $0.9 \mathrm{~V}$. At $333 \mathrm{~K}$, it can be seen in (Fig. 9(a) and (b)) that the hydrogen mass fraction decreases from $80 \%$ to $67 \%$ at $0.7 \mathrm{~V}$ and from $80 \%$ to $73 \%$ at $0.9 \mathrm{~V}$.
The mass fraction of hydrogen decreases along $\mathrm{z}$-direction because hydrogen is consumed from $\mathrm{z}=0$ $\mathrm{mm}$ to $\mathrm{z}=50 \mathrm{~mm}$. The hydrogen is oxidized to give two hydrogen ions $\left(2 \mathrm{H}^{+}\right)$and two electrons $\left(2 \mathrm{e}^{-}\right)$ (oxidation reaction) at the anode catalyst layer and the membrane. On the other hand, the oxygen recombines with hydrogen ions to form water and heat at the cathode catalyst layer and membrane ${ }^{23,24,}$ 30 .

\section{For 343 K}

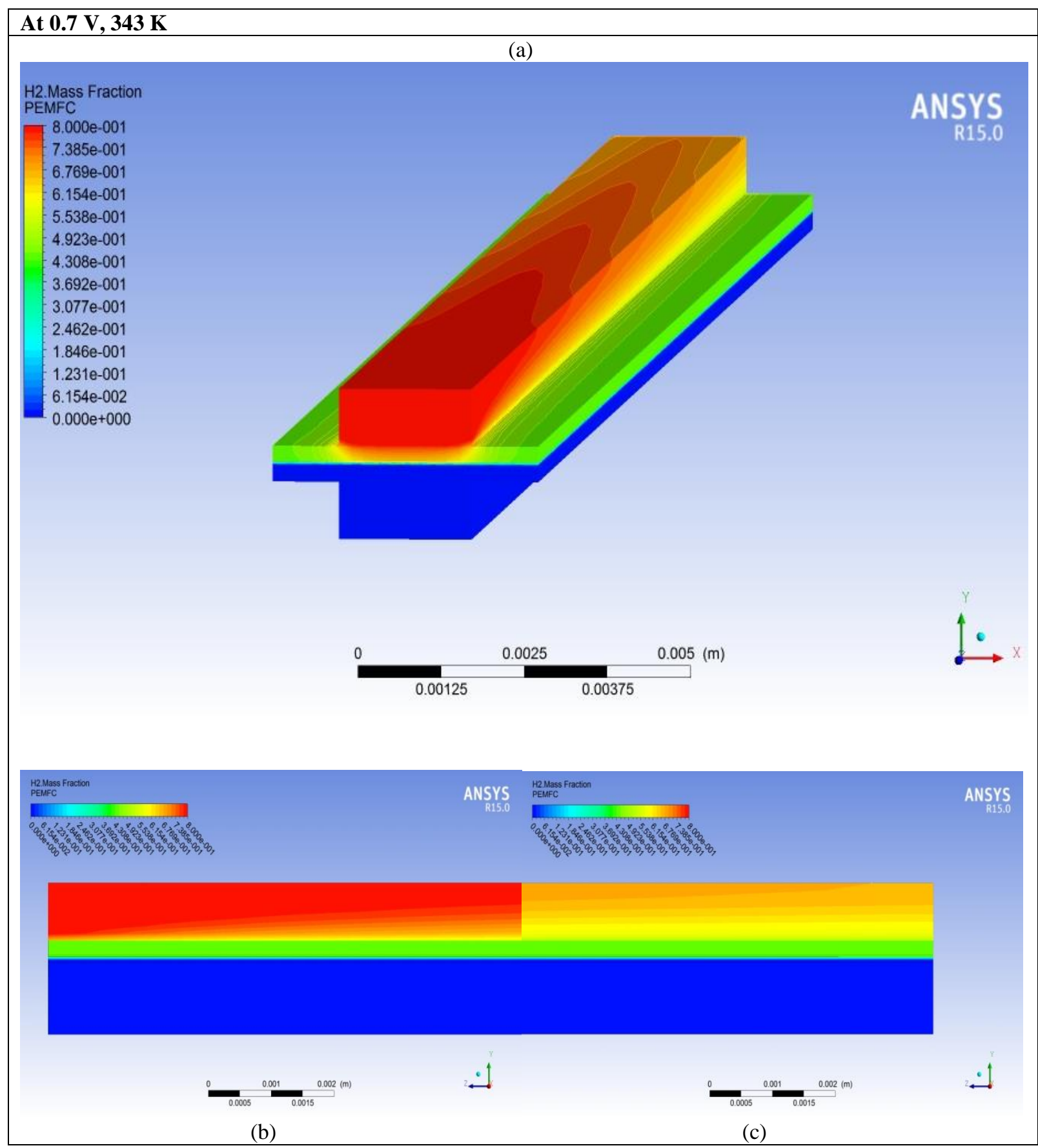

Figure 10. $\mathrm{H}_{2}$ mass fraction distribution in the anode channel: (a) Three-dimensional model, (b) The 


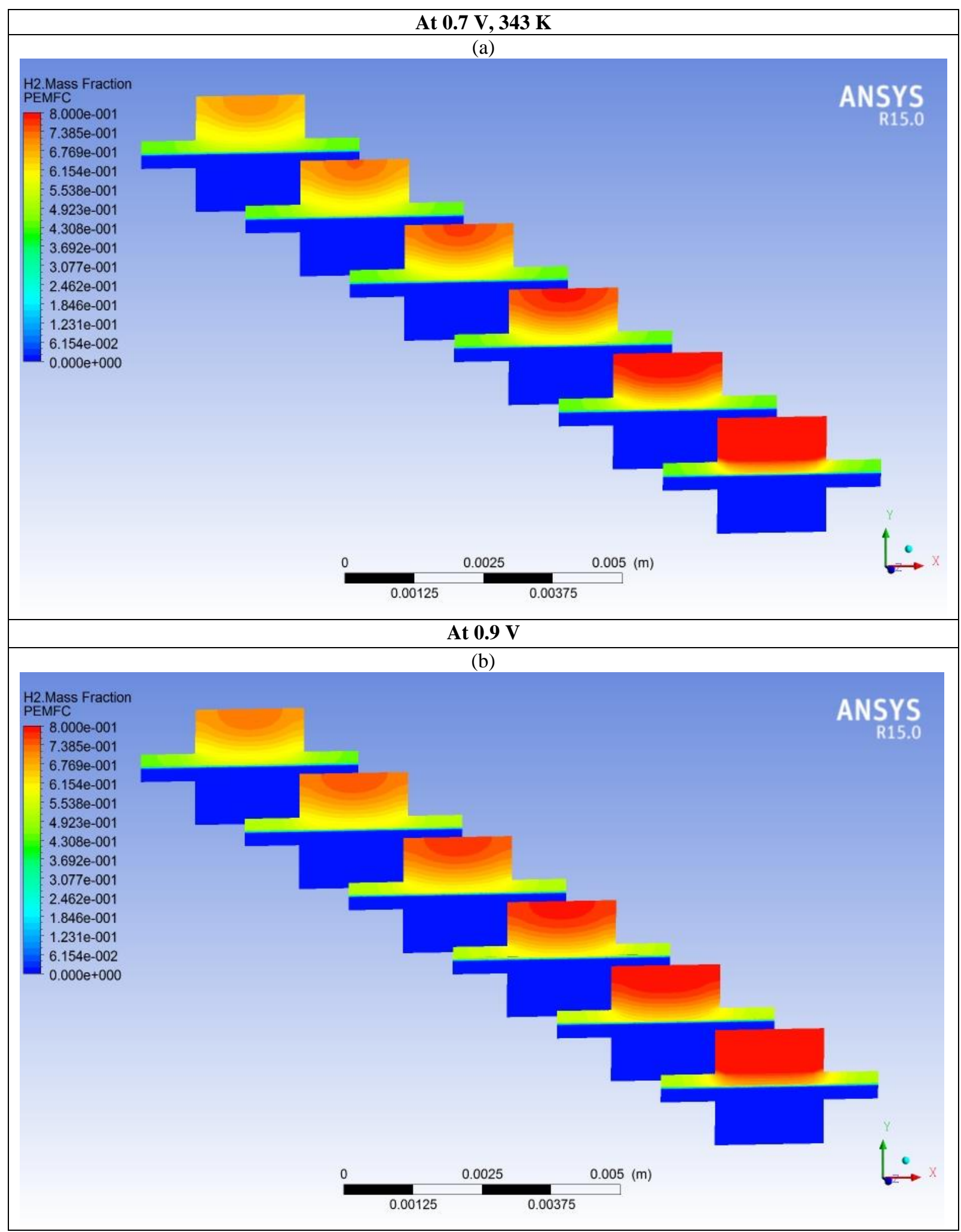

Figure 11. $\mathrm{H}_{2}$ mass fraction distribution in PEMFC, (a) $0.7 \mathrm{~V}$ and (b) $0.9 \mathrm{~V}$ at $\mathrm{T}=343 \mathrm{~K}$. For six planes from $\mathrm{z}=0 \mathrm{~mm}$ to $\mathrm{z}=50 \mathrm{~mm}$. 


\section{For 353 K}

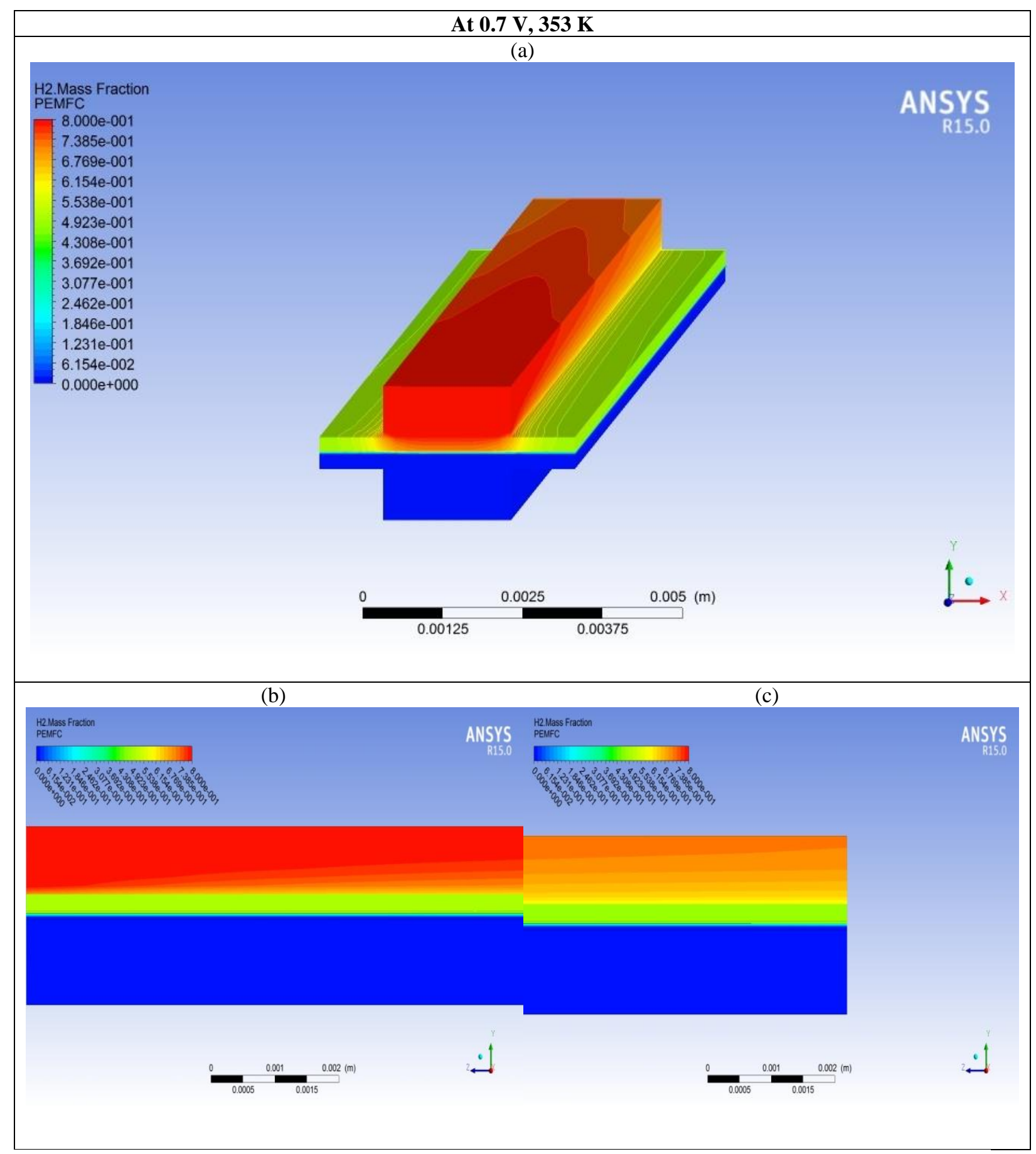

Figure 12. $\mathrm{H}_{2}$ mass fraction distribution in the anode channel: (a) Three-dimensional model, (b) The beginning of the anode channel, (c) The end of the anode channel, $353 \mathrm{~K}$. 


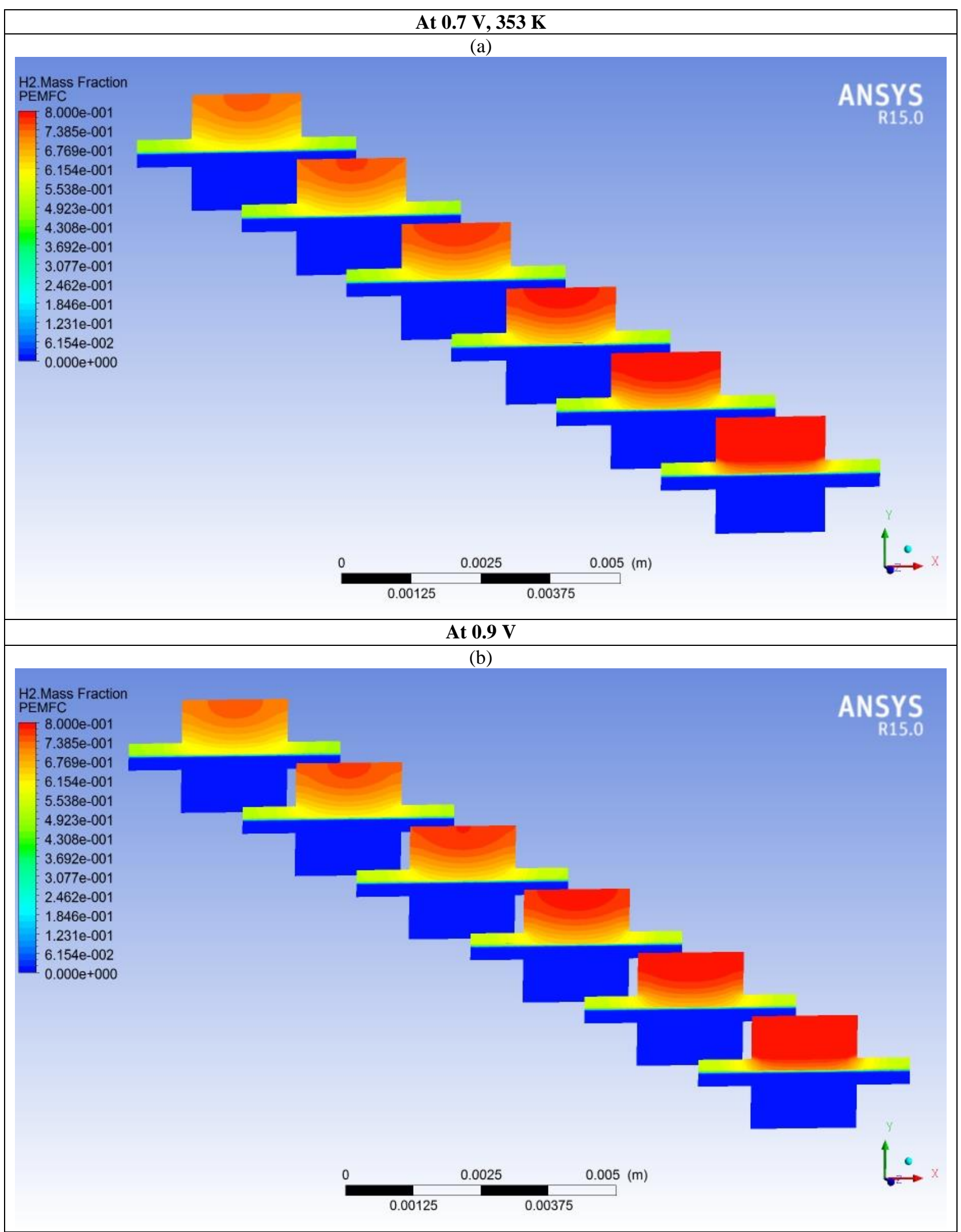

Figure 13: $\mathrm{H}_{2}$ mass fraction distribution in PEMFC, (a) $0.7 \mathrm{~V}$ and (b) $0.9 \mathrm{~V}$ at $\mathrm{T}=353 \mathrm{~K}$.

For six planes from $\mathrm{z}=0 \mathrm{~mm}$ to $\mathrm{z}=50 \mathrm{~mm}$.

(Fig.10) shows the evolution of hydrogen mass fraction along the anode side of the single PEM fuel cell at $\quad \mathrm{V}=0.7 \mathrm{~V}$. 3D numerical analysis investigating the distribution of hydrogen along the anode channel show a decrease in hydrogen mass fraction (in the flow direction).

(Fig. 11) represents the hydrogen mass fraction evolution along the anode channel for six planes 
$(\mathrm{z}=0.0 \mathrm{~mm}, \mathrm{z}=10 \mathrm{~mm}, \mathrm{z}=20, \mathrm{z}=30 \mathrm{~mm}, \mathrm{z}=40 \mathrm{~mm}$, and $\mathrm{z}=50 \mathrm{~mm}$ ) of the single PEM fuel cell at $0.7 \mathrm{~V}$ and $0.9 \mathrm{~V}$.

At $343 \mathrm{~K}$, as observed in (Fig. 11 (a) and (b)), the hydrogen mass fraction is at a maximum of $80 \%$ at the inlet and decreases gradually to $61 \%$ for $0.7 \mathrm{~V}$ and from $80 \%$ to $67 \%$ for $0.9 \mathrm{~V}$.

At $353 \mathrm{~K}$, the hydrogen mass fraction shows no significant change from $\mathrm{z}=0 \mathrm{~mm}$ to $\mathrm{z}=50 \mathrm{~mm}$ for $0.7 \mathrm{~V}$ and $0.9 \mathrm{~V}$. The hydrogen enters the anode side at a maximum mass fraction of $80 \%$ and exits at a mass fraction of $72 \%$. There is a gradient of $8 \%$ in hydrogen mass fraction across this flow channel.
Our study shows a high consumption of hydrogen at low voltages; consequently, the higher amounts of water are consumed at low cell voltages to keep the membrane wet ${ }^{25,26}$. Depending on the hydration state of the membrane, proton migration is associated with a drag of water molecules from the anode to the cathode side. The electro-osmotic drag transport, together with electrochemical water production, results in an accumulation of water at the cathode side. In turn, the water concentration gradient between the anode and cathode causes back diffusion, which works against drying of the membrane from the anode side ${ }^{18}$.

\section{Distribution of water mass fraction and relative humidity in PEMFC}

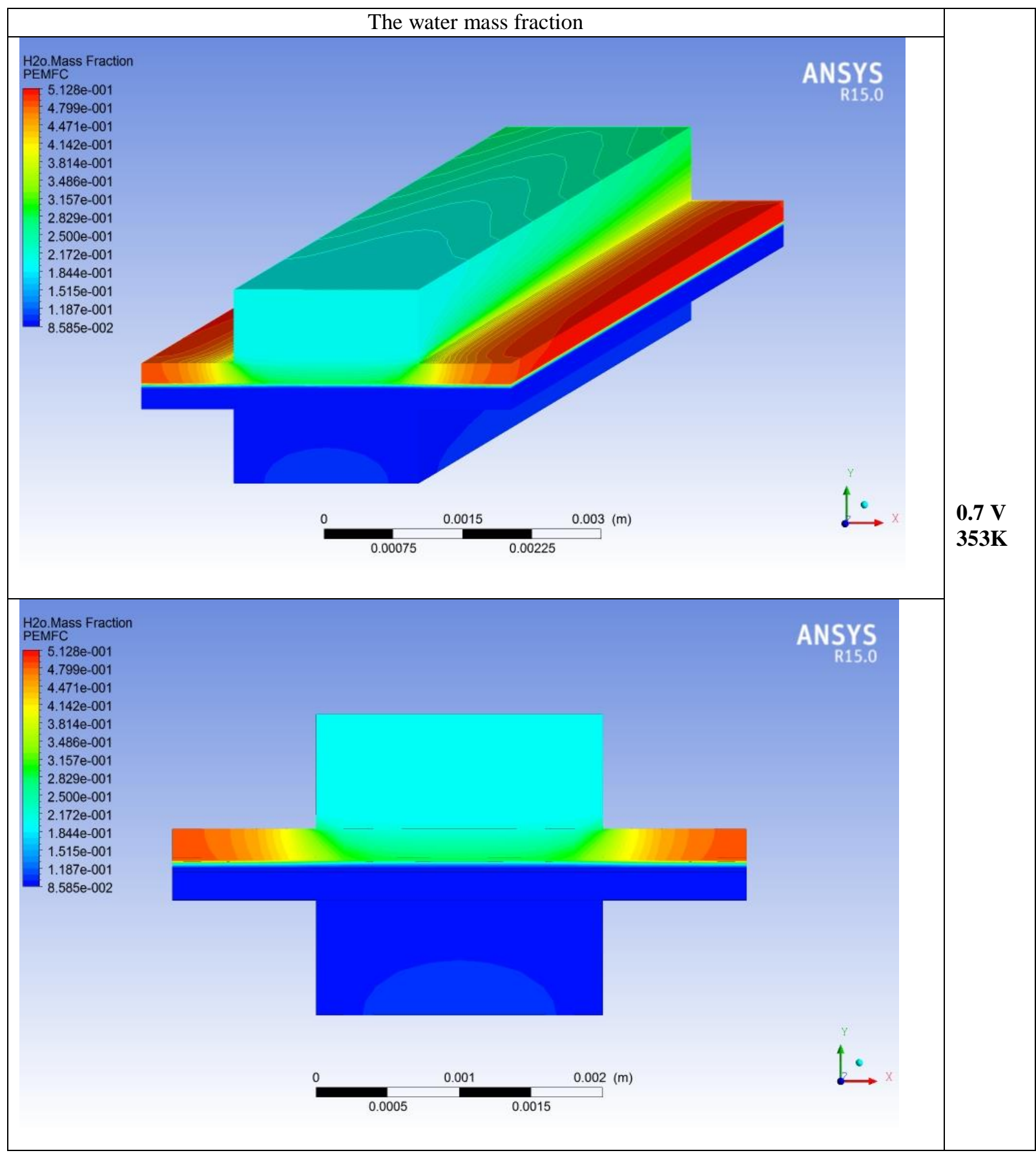

Figure 14. Water mass fraction distribution at $353 \mathrm{~K}, 0.7 \mathrm{~V}$. 


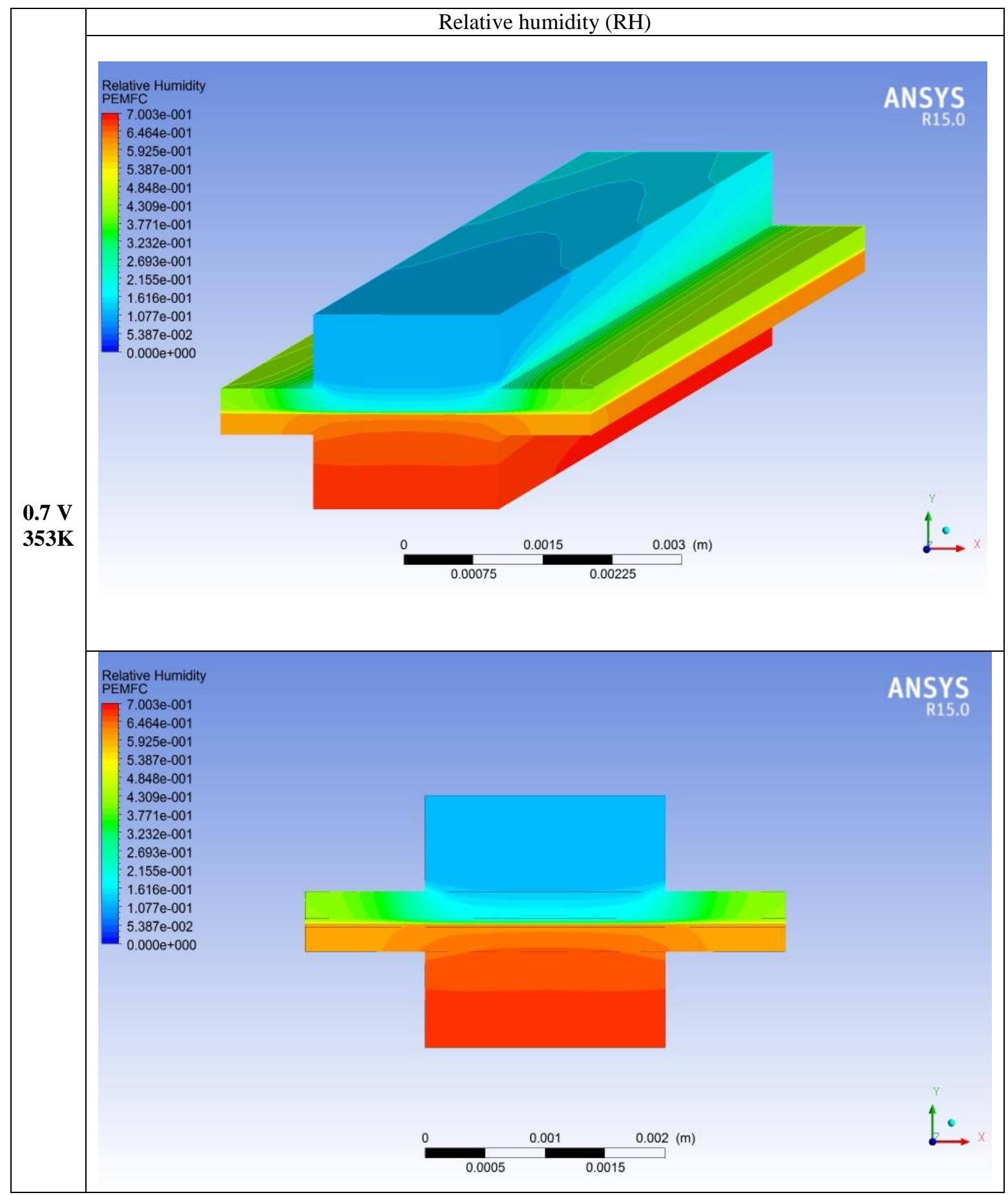

Figure 15. Relative humidity at $353 \mathrm{~K}, 0.7 \mathrm{~V}$.

A comparison of the water mass fraction distribution and relative humidity at low voltage is presented in (Fig. 14) and (Fig. 15).

It can be seen in Fig. 14 that the water mass fraction at the inlet of the channel is 0.18 and increases to 0.28 as flows reach the outlet. The highest values of water mass fraction, 0.51, are found in the gas diffusion layer (GDL) where the reaction takes place.

Fig. 15 shows that the relative humidity is very higher in the cathode channel, cathode gas diffusion layer, membrane than in the anode regions ${ }^{27,28,30}$. 


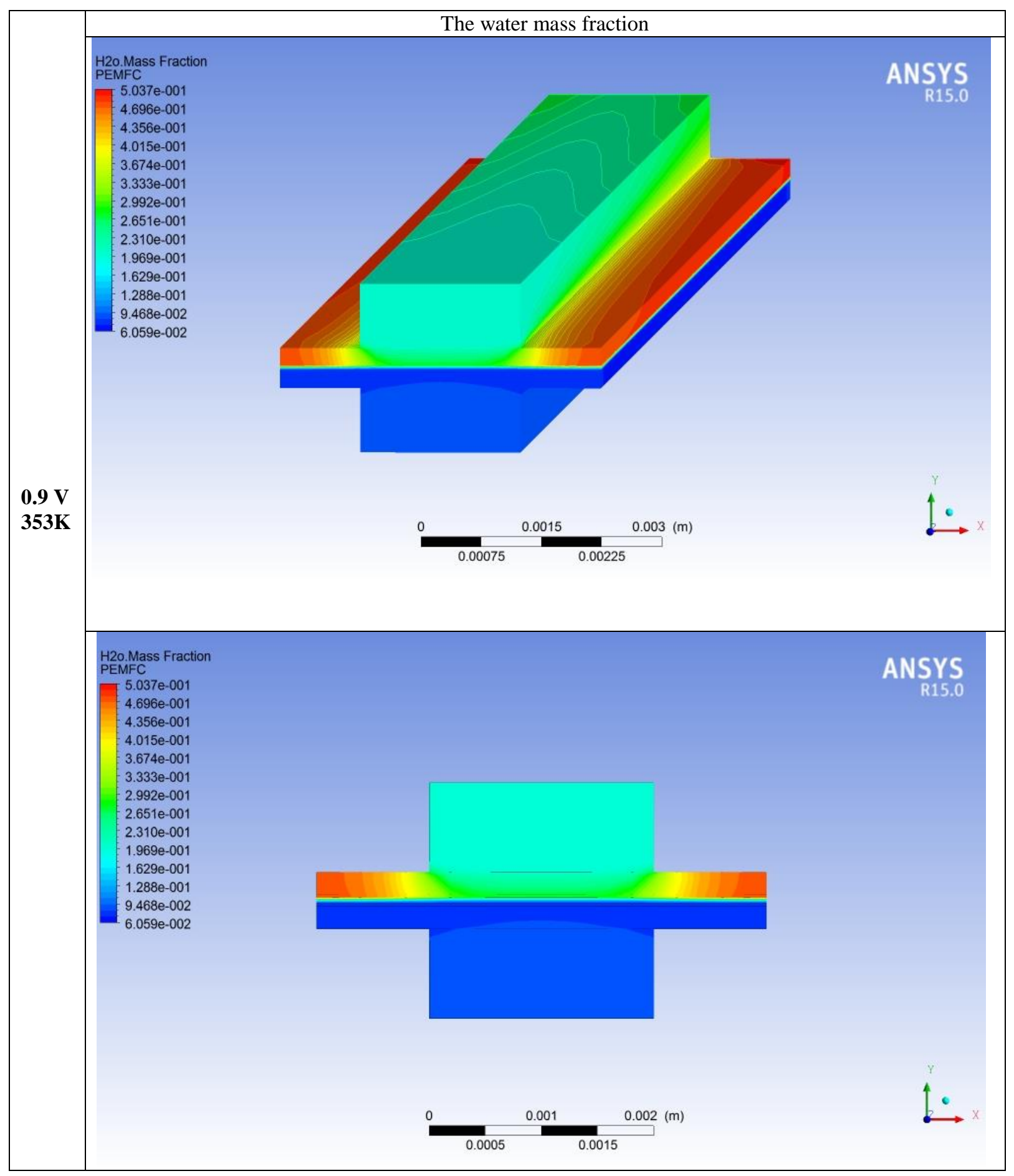

Figure 16. Water mass fraction distribution at $353 \mathrm{~K}, \mathrm{~V}=0.9 \mathrm{~V}$.

A comparison of the water mass fraction distribution and relative humidity at high voltage is presented in (Fig. 16) and (Fig. 17).

The water mass fraction generated is shown in (Fig. 16), at the cell inlet the water mass fraction is 0.22 , and it increases to 0.28 at the outlet. As before, the majority of water generated in the cell is stagnating in the gas diffusion layer (GDL).

(Fig. 17) shows that the relative humidity is lower in the anode regions and membrane than in the cathode regions. It can be seen that the relative humidity increases as the operation cell voltage decreases. The relative humidity is low at $0.9 \mathrm{~V}$ and high at $0.7 \mathrm{~V}$. This behaviour is quite clear because at low cell voltages the chemical reaction rate becomes higher. Liquid water plays a key role in the hydrating membrane, but also it blocks the transport of oxygen to the cathode catalyst layer ${ }^{31}$. This factor has a negative effect on overall cell performance. 


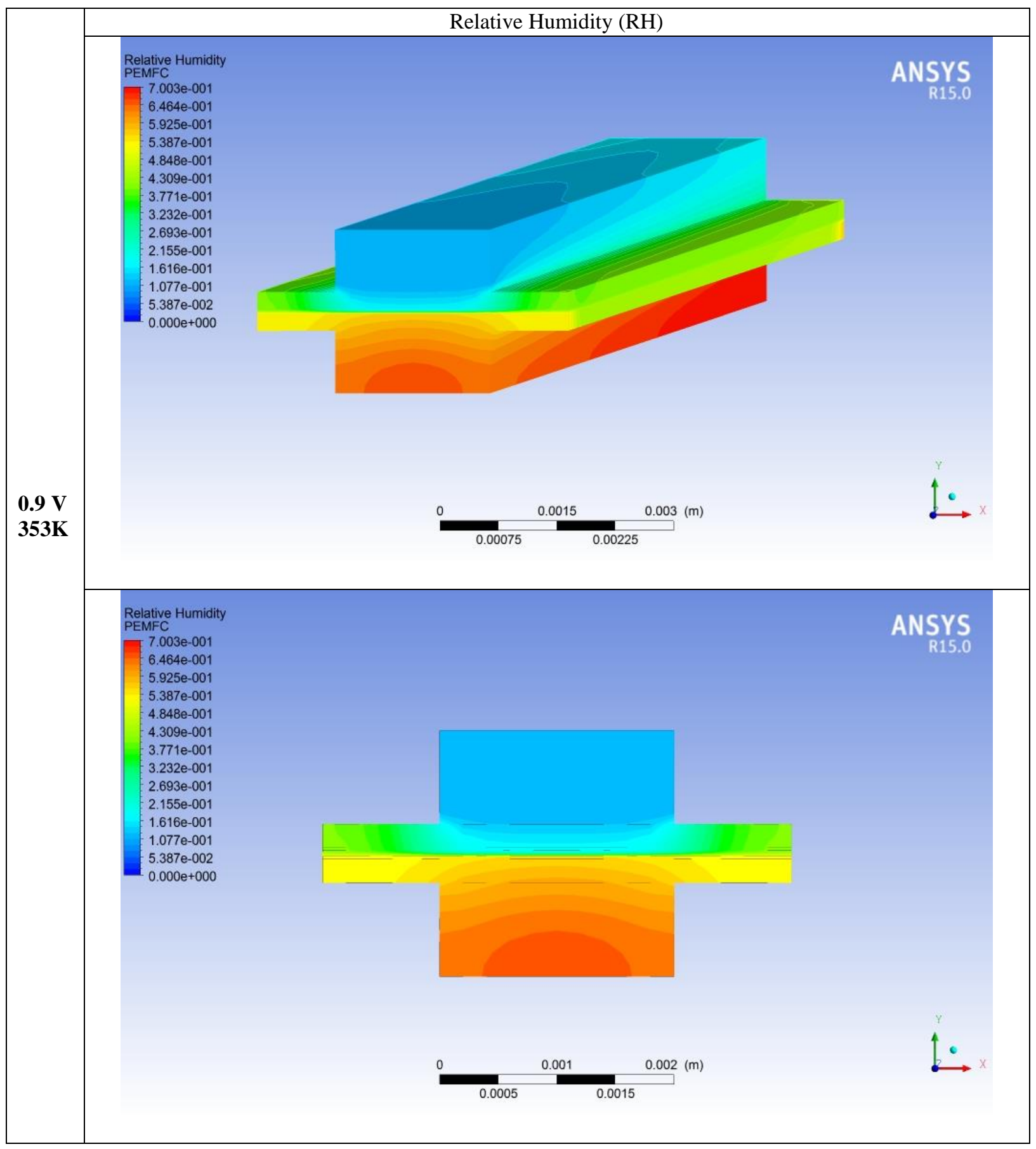

Figure 17. Relative humidity at $353 \mathrm{~K}, \mathrm{~V}=0.9 \mathrm{~V}$.

\section{Conclusion}

In this research paper, a thermo-fluid model is established to study the hydrogen and water dynamics in PEMFC. The simulation approach is validated by comparing our findings with the experimental results. The effects of temperature and cell voltage on the consumption of hydrogen are examined in this paper. The hydrogen mass fraction and water mass fraction are analyzed.

The results showed that:

- The amount of hydrogen decreases along the $\mathrm{z}$ axis from plane $1(\mathrm{z}=0 \mathrm{~mm})$ to plane $6(\mathrm{z}=50 \mathrm{~mm})$.
- At $343 \mathrm{~K}$, the mass fraction of hydrogen has significant decrease along the anode channel from the inlet to outlet by $19 \%$ at $0.7 \mathrm{~V}$ and $13 \%$ at $0.9 \mathrm{~V}$.

- The hydrogen consumption was carried out by chemical reactions.

- There is high consumption of hydrogen at low cell voltages.

- The analysis of water production at the cathode side showed a high value of water content at low cell voltages. 


\section{Acknowledgements}

We thank all the members of Research Team EMISys, Research Centre ENGINEERING 3S.

\section{References}

1- J. Brouwer, On the role of fuel cells and hydrogen in a more sustainable and renewable energy future, Current Applied Physics, 2010, 10, 9-17.

2- J. Wang, H. Wang, Y. Fan, Techno-economic challenges of Fuel Cell Commercialization, Engineering, 2018, 4, 352-360.

3- M. Reza Kazemi, I. Heydari, Z. Zhang, Hybrid systems: combining membrane and absorption technologies leads to more efficient acid gases $(\mathrm{CO} 2$ and $\mathrm{H} 2 \mathrm{~S})$ removal from natural gas, Journal of CO2 utilization, 2017, 18, 362-369.

4- D.O. Akinyele, R.K. Rayudu, Review of energy storage technologies to sustain power networks, Sustainable Energy Assess, 2014, 8, 74-91.

5- J.Y. Wang, Barriers of scalling-up fuel cells: cost, durability and reliability, Energy, 2015, 80, 509-521.

6- M. Al-Baghdadi, H. Al-Janabi, Modeling optimizes PEM fuel cell performance using three-dimensional multi-phase computational fluid dynamics model, Energy Convers. Manage, 2007, 48, 3102-3119.

7- J.H. Lin, W.H. Chen, Y.J. Su, T.H. Ko, Effect of gas diffusion layer compression on the performance in a proton exchange membrane fuel cell, Fuel, 2008, 87, 2420-2424.

8- I. Tolj, M. Lototskyy, M. Davids, S. Pasupathi, G. Swart, B. Pollet, Fuel cell-battery hybrid powered light electric vehicle (golf cart): Influence of fuel cell on the driving performance, International Journal of Hydrogen Energy, 2013, 38, 10630-10639.

9- J. T. Hinatsu, M. Faulkner, H. Takenaka, water uptake of perfluoro sulfonic acid membranes from liquid water and water vapour, Journal of the electrochemical society, 1994, 141, 1493-1498.

10- E. Ozden, I. Tari, Proton exchange membrane fuel cell degradation: A parametric analysis using Computational Fluid Dynamics, J. Power Sources, 2016, 304, 64-73.

11- H. F. Hashemi, S. Rowshanzamir, M. Reza Kazemi, CFD simulation of PEM fuel cell performance: effect of straight and serpentine flow fields, Math Comput Model, 2012, 55, 1540-1557.

12- H. Mahayri, H. Hassanzadeh, M.S Afrouzi, Three-dimensional transient multiphase flow simulation in a dead end anode polymer electrolyte fuel cell, Journal of molecular liquids, 2017, 225, 391-405.

13- H. K. Esfeh, A. Azarafza, M. K. A. Hamid, On the computational fluid dynamics of PEM fuel cells (PEMFCs): an investigation on mesh independence analysis, RSC Adv., 2017, 7, 32893-32902.

14- E. Hontañón, M.J. Escudero, C. Bautista, P.L. García-Ybarra, L. Daza, Optimisation of flowfield in polymer electrolyte membrane fuel cells using computational fluid dynamics techniques, Journal of Power Sources, 2000, 86, 363-368.

15- W. Ying, M. Ouyang, Three-dimensional Heat and Mass transfer analysis in an air-breathing proton exchange membrane fuel cell, Journal of Power Source, 2007, 164, 721-729.

16- H. Zhang, P. Pei, X. Yuan, The conception of the in-plate adverse-flow field for a proton exchange membrane fuel cell, Int. J. Hydrog. Energy, 2010, 35, 9124-9133

17- Inc. ANSYS FLUENT 12.0 fuel cells module manual, April 2009.

18- T.E. Springer, T.A. Zawodzinski, S. Gottesfeld, Polymer electrolyte fuel cell model, Journal of the Electrochemical Society, 1991, 138, 2334-2342.

19- L. Wang, A. Husar, T. Zhou, H. Liu, A parametric study of PEM fuel cell performances, Int. J. Hydrog. Energy, 2003, 28, 1263-1272.

20- A. Arvay, A. Ahmed, X.H. Peng, A.M. Kannan, Convergence criteria establishment for 3D simulation of proton exchange membrane fuel cell, Int. J. Hydrog. Energy, 2012, 37, 2482-2489.

21- C.M. Baca, R. Travis, M. Bang, Threedimensional, single-phase, non-isothermal CFD model of a PEM fuel cell, J. Power Sources, 2008, 178, 269-281.

22- P. K. Takallo, E. S. Nia, M. Ghazi khan, Numerical and experimental investigation on effects of inlet humidity and fuel flow rate and oxidant on the performance on polymer fuel cell, Energy Conversion and Management, 2016, 114, 290-302.

23- A. Awan, M. Saleem, A. Basit, Simulation of proton exchange membrane fuel cell by using ANSYS Fluent, IOP Conf. Ser.: Mater. Sci. Eng, 414, 2018, 1-10.

24- A. Iranzo, M. Muñoz, J. Pino, F. Rosa, Update on a numerical model for the performance prediction of a PEM fuel cell, Int. J. Hydrog. Energy, 2011, 36, 9123-9127.

25- T. Berning, N. Djilali, Three-dimensional computational analyses of transport phenomena in a PEM fuel cell, Journal of Power source, 2002, 106, 284-294.

26- D.G. Sanchez, T. Ruiu, I. Biswas, K. A. Friedrich, J. S. Monreal, M. Vera, Effect of the inlet gas Humidification on PEMFC Behavior and Current Density Distribution, ECS Trans., 2014, 64, 603-617.

27- T. V. Nguyen, R. E. White, A water and thermal management model for proton exchange membrane fuel cells, Journal of Electrochemical society, 1993,140, 2178-2186. 
28- J. Zhang, Y. Tang, C. Song, Z. Xia, H. Li, $\mathrm{H}$. Wang, J. Zhang, PEM fuel cell relative humidity $(\mathrm{RH})$ and its effect on performance at high temperatures, Electrochimica Acta, 2008, 53, 5315-5321.

29- Y. Amadane, H. Mounir, A. El Marjani, Modeling the Temperature Effect on PEM fuel cell performance, ICTEA, Vol 2018 (2018), 2018, 1-3.
30- E. Misran, N.S.M. Hassan, W.R.W. Daud, E.H. Majlan, M.I. Rosli, Water transport characteristics of a PEM fuel cell at various operating pressure and temperatures, Int. J. Hydorg. Energy, 2013, 38, 9401-9408.

31- M. Ji, Z. Wei, A review of water management in Polymer Electrolyte Membrane Fuel Cells, energies, 2009, 2, 1057-1106. 